Adrian MRÓZ ${ }^{1}$

\title{
THE "WORK” OF ART: STANISŁAW BRZOZOWSKI AND BERNARD STIEGLER
}

This article relates the ideas of Stanisław Brzozowski (1878-1911) with those of Bernard Stiegler (1952-2020), both of whom problematize the "work" of art understood as a labor practice. Through the conceptual analysis of epigenetics and epiphylogenetics for aesthetic theory, I claim that both thinkers develop practical concepts relevant to contemporary art philosophy. First, I present an overview of Brzozowski's aesthetics, for whom literature and the arts are linked with ethics, and aesthetic form is tied with moral judgment. Then, I continue with an outline of Stiegler's, for whom the role of artists is to sculpt a new culture and historical epoch called the Neganthropocene. Finally, the notion of "work" as a type of memory practice is analyzed. The comparison shows that Stiegler develops epigenetics phenomenologically via memory ("tertiary retentions") and phylogenetics to epiphylogenetics. Both philosophers argue against determinism. This study suggests that their key ideas advance and complement each other.

Keywords: art, work, Bernard Stiegler, Stanisław Brzozowski, aesthetics, Marxism.

\section{INTRODUCTION}

This essay ${ }^{2}$ is a conceptual analysis of the socio-economic and equivocal notion of "work" present in the thought of two significant philosophers and within the philosophy of art. In response to a call for submissions for a congress on Polish philosophy, this essay aims to develop some idiosyncratic elements of Brzozowski's reflections, rooted in Polish intellectual and cultural heritage in search of the originality of Polish philosophy. Moreover, if the universality of thought is to be scrutinized, it would probably be best to compare the reflections of at least two philosophers from different cultures. It is common knowledge that travel is an excellent way to change one's immediate surroundings and modify one's exposition to the complex conditions of social-cultural cognition, such as heuristics, behavioral programs, and patterns, or traditions (Wojciszke, 2019). Metaphorically speaking, this essay travels in time, from the early $20^{\text {th }}$ century to the $21^{\text {st }}$ century, and across cultures, from Poland to France and back again.

${ }^{1}$ Adrian Mróz, M.A., Department of Aesthetics at the Institute of Philosophy of the Jagiellonian University in Kraków, 52 Grodzka St., 31-044 Kraków; e-mail: adrian@doctoral.uj.edu.pl. ORCID: 0000-0001-6813-7490.

2 This essay was presented remotely at the First Congress of Polish Philosophy organized by the University of Opole and held on September 25-26, 2020 at the renovated palace in Orla, Krotoszyn County, and digitally via Korbank teleconference systems. 
There may be an objection that this comparison is anachronistic, but it should be noted that philosophers - despite living in different times - universally search for truths that transcend their epochal conditions. For instance, contemporary philosophers still find inspiration in the two-thousand-year-old writings of their predecessors, such as Plato and Aristotle. In addition, from the perspective of evolution, humans' biological, cognitive faculties could not have significantly changed within a century. However, their technologies of "extended cognition" (Clark \& Chalmers, 1998) have, which is a point I will return to later. In other words, the epochal ${ }^{3}$ situation is not irrelevant. So, to study Polish philosophical thought, I have selected one feature that both philosophers share as a point of reference. They belong to what we could call the present epoch that has been shaped in some respect by the Industrial Revolution, which provided the grounds for Marxism to take root in Europe (Hobsbawm, 2013). Consequently, both authors have been selected due to their similarity in this regard. The two continental thinkers will be read with and against each other to identify universalities and their cultural similarities and differences.

The two philosophers selected for analysis are Stanisław Brzozowski (1878-1911) and Bernard Stiegler (1952-2020). This selection is motivated by the fact that both thinkers share similarities despite their chronological and cultural separation. Both thinkers analyzed in this essay write about labor practices within the framework of the philosophy of art, where special attention is given to the notion of "work", understood as both artwork (product) and labor (process). Brzozowski's core idea is based on the concept of a socially engaged intellectual or artist. Culture constitutes work, and work constitutes culture.

Brzozowski argued that literature and the arts were linked with ethics, where aesthetic form concerns moral judgment (Stanisław Brzozowski, 2010). Likewise, Stiegler's core idea is based on the problem of individuation and the concept of the work [ouvre] (as distinguished from employment or use) of art as a social sculpture, which he developed while analyzing the practice of the German artist Joseph Beuys (Fitzpatrick, 2014; Stiegler, 2017b; 2017a; 2017c). His 2018 lecture at the Work Marathon is especially noteworthy ${ }^{4}$.

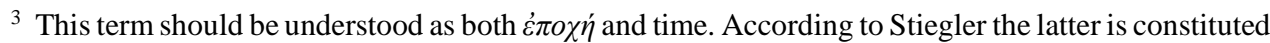
by technics, especially novel inventions that disorder, shock, and suspend cultural norms and practices. Phenomenologically, the notion of epoché, "epokhē", or a detachment is reconsidered in light of the phenomenon of retention. When it comes to the discipline of aesthetics, revolutions in the technologies adopted by artists disrupt shared thinking, i.e. feeling and being-what had been previously "retained" by traditions and practices, which are materialized in the tools and instruments of art, called "tertiary retentions". Furthermore, psycho-social individuation is negatively affected by alienation brought about via innovation or technology that has not been properly socialized. During the absence of a re-constituted epoch, this break results in one undergoing "symbolic misery" and a feeling of hopelessness or no common future, which all lead to transgression or acting out. These "epochal" shocks require cultural programs of "therapy", which are "thoughtful" practices of rational care that reintegrate disruptive technics within ethnic tradition through interand intra-generational processes of individuation, shaping a contributively shared vision of a desired future of the affected society, thus re-constituting an epoch. (Stiegler, 1998a; 1998b; 2011; 2014a; $2015 ; 2019$ ).

${ }^{4}$ The Work Marathon - an international bringing-together of artists, sociologists, anthropologists, writers, musicians, architects, scientists and philosophers - was held on September 22, 2018 at the Serpentine Galleries in London of the United Kingdom. That is where swiss art curator Hans Ulrich Obrist and Stiegler initiated debate on the future of work in the $21^{\text {st }}$ century. A distinction should be

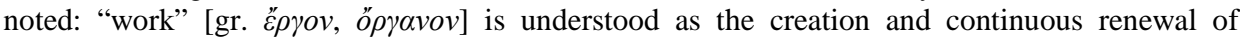
knowledge. It is not equal to "employment" (a use, which could be mindless and nonreflective), nor 
Besides that, Stiegler argues, particularly in Symbolic Misery, that the separation of politics from aesthetics (understood broadly as $\alpha i ̈ \sigma \eta \eta \sigma l \varsigma)$ is a catastrophe (Stiegler, 2014a; 2015). For him, the role of artists is to sculpt a new culture and historical epoch, which he envisions as "The Neganthropocene" (Stiegler, 2018). Stiegler's philosophy consists of the politicization of phenomenology and the anthropogenic importance of the default [défaut], understood existentially as a type of inadequacy, and advances the significance of failure and absence (Stiegler, 1998a; 1998b; 2011). In addition, both philosophers apply the notion of historic epigenetics, where Stiegler expands the notion to include memory (tertiary retentions) in terms of phylogenetics (what he calls "epiphylogenetics"). Both argue against determinism (Stanisław Brzozowski, 1910a; 1910b; Stiegler, 1998b).

First, I present a sketch of the philosophy of art of Brzozowski. I follow this with an overview of the aesthetics of Stiegler. I then claim that the writing of both philosophers advances each other's philosophies in a valuable way. I briefly compare Brzozowski's epigenetic theory of history and Stieglerian "epiphylogenetics" in Technics and Time. After that, I argue that much of the Polish thinker's key ideas advance and complement the philosophy developed by Stiegler, whose ideas, in turn, advance Brzozowski's thinking. What makes Polish philosophy distinct in this regard is that we can see that Brzozowski was "ahead of his time," so to speak.

\section{A BRIEF OUTLINE OF STANISŁAW BRZOZOWSKI'S AESTHETICS}

As Tadeusz Szkołut asserts, one of Brzozowski's aims was to advance Polish culture through the development of philosophical and humanistic thought, which hopefully would produce a national culture that could face the main problems that arise out of modernity (Szkołut, 2008). At the same time, Brzozowski's controversial intellectual activity was not contained by strict disciplinary boundaries; instead, he wrote inter-disciplinarily. The Polish thinker connected and used various perspectives - whose separation was treated as relative and disputable -such as the philosophy of culture, poetry, literature, theater, art criticism, sociology, and political journalism. He viewed culture, which served the demands of Life in a broad sense, as an organic formation and art as the nucleus of the historical and social phenomena that constitute an axiological culture.

During the early $20^{\text {th }}$ century, he noticed that the main problem with modernity lies in the expansion of a "historical sense" and post-romantic individualism, which paradoxically erodes personality and undermines individuality itself. Individualism refers to a person having strong, clearly defined convictions which condition their fitness (and will) to act (Stanislaw Brzozowski, 2007). However, this same "historical sense" also is essential for artistic creation and involves empathy or the ability to feel what the Other feels. In his works Gtosy wśród nocy [Voices in the Night] and Sztuka i społeczeństwo [Art and Society], he maintains that the emergence of a psyche (or I) is mutually conditioned by the social. The optimal conditions that cultivate a rich personality are beneficially allied with diverse, abundant, and intensive living relationships between autonomous individuals who compose a sentient and self-conscious culture. In its own best interest, society should take care of ensuring an individual's freedom to act (operate, put in the effort, take measures, in other words: work), thereby fostering their spirit and creative potential. Of course, we all belong 
to many social circles, affecting one's worldview and behaviors. This belonging is why the ability to empathize with others and tune into their different psyches without losing one's sense of self is crucial for pursuing a shared future. Dissolving one's own identity - as the power of making decisive choices concerning worldview and values - into an externality then results in a grave paralysis of creative potential.

Moreover, Brzozowski distinguishes artistic truth, defined by authenticity, which is treated as a moral value and protects personality from artistry, conceived of as the persistent and socially detached post-romantic pursuit of new ways of expression. Art, a psychosocial phenomenon, must invent remedies in the struggle against artistry, against modernistic nihilism, which are expressions of generational pessimism and feelings of exhaustion. Szkołut affirms that for Brzozowski, art is not an end in itself; the fundamental goals of art lay outside art in the realm of social and cultural reality. In terms of motivation, this reality is the only "absolute" reference point available to a person within which they can exercise their creative powers: it is necessary to believe in something outside art in order not to be imbibed by art, but instead be its master; it is necessary to aspire to something beyond art in order to resist art (Szkołut, 2008).

More importantly, Brzozowski treats artwork as work. Artistic creation is a form of labor that exercises freedom and which spontaneously develops and invents itself. It is constituted in effort and overcoming resistance, which takes time, multiple failures, false starts, torment, anguish, and bitterness. The primary goals of art appear in the artist's spirit, but the far-reaching ends of art, the effects of artwork, and the creative process are to be situated in the social sphere. The creation of an artwork is the construction of a new world within which the experience of freedom reigns. This experience liberates the artist's desires and aspirations, which generally are inhibited in social reality. As an expression of spirit, the work involved in making art enhances personality by emancipating drives and desires that work on society. In other words, art's remedial function unifies the individual and the social, anticipating a different social future for all parties involved in the work of art. Art is a discipline of shared spiritual freedom for everyone.

Brzozowski claims that the standard measure of all values is the quality of the act aroused by them. He develops the notion of an activistic individuality. This notion is tinged with an optimistic belief in the possibility of transforming the world to make a place for authentic freedom in the creative act. What is at stake is creating a framework for developing an integrated, strong personality capable of fulfilling intangible activity. The future culture should be an integral one, in which every person's freedom to fulfill themselves in the creative act completely constitutes an inalienable right. The arts, supported by art criticism, contribute to establishing an environment conducive to the proliferation of the values of liberty, activity, and creativity. It is a form of organizing the consciousness of the arts.

\section{A SKETCH OF THE AESTHETICS OF BERNARD STIEGLER}

The following sketch is written in comparison and contrast to the previous one. The philosophy of art of the continental philosopher Bernard Stiegler is also situated within a wide-ranging politicized inter-disciplinary approach that draws on phenomenology, existentialism, deconstruction, post-structuralism, critical theory, and anti-consumerism, media theory, Marxism, psychoanalysis, anthropology, and classical Greek philosophy. His opus magnum, three published volumes with the main title Technics and Time (with several 
unpublished volumes), are works that analyze the notion of $\tau^{\prime} \chi v \eta$ in-depth and lay the foundation for the critique of the financial politicization of aï $\theta \eta \eta \check{\iota} \varsigma$ (understood broadly as sensibility: feeling and sensory perception), especially within the context of industrialization and deliberations on technological advancements. Subsequently, Stiegler claims that "aesthetic war" is waged against the "oeuvre" of aesthetic experience in general since the symbolic follows the hegemonic rules of the market and industrial development, which is criticized for aesthetic conditioning. As a digression, Annie Le Brun's notion of "globalist realism" complements this understanding well (Le Brun, 2018). Le Brun argues that a catastrophic war is indeed being waged on that "which is priceless," such as beauty, sleep, boredom, the ability to think for oneself, and all other valuable aspects of life, which make life worth living and escape what she describes as the wasteful short-sighted violence of financialization (Velthuis \& Coslor, 2012). Nonetheless, further comprehensive analysis on aesthetics by Stiegler can be found in the two volumes of Symbolic Misery, where he discusses the works of Alain Resnais, Bertrand Bonello, Andy Warhol, and Joseph Beuys. Additional texts on the philosophy of art can be found scattered throughout his corpus, such as in an issue by the journal Boundary 2, titled "Bernard Stiegler: Amateur Philosophy".

One of Stiegler's aims is to elevate the value of the spirit [esprit] (Stiegler, 2014b) or de-proletarianize contemporary industrial consciousness. Through the association Ars Industrialis $^{7}$ he worked to create a new economic model rooted in contribution. Through the organization Internation ${ }^{8}$, he aimed to cultivate the becoming of what is called the Neganthropocene. This new culture now faces problems that arise out of globalization, climate change, and neoliberalism. However, Stiegler argues that culture is technics. Technics is problematized as a method of pursuing the demands of life through ways foreign to life. He develops this thinking in terms of negentropy and anti-entropy. Art is studied within the framework of a methodology Stiegler coined as General Organology. This term borrows from the practices of musicology but generalizes to include all instruments of humanity. General Organology analyzes the mutual relationship between a triad of organs: biological organs, artificial organs, and social organizations. He applies this method to the

\footnotetext{
${ }^{5}$ Understood as both the work of art - as an intermittent struggle, activity, and labor or birthing - and an opening - singularity and indeterminacy.

${ }^{6}$ This term alludes to Socialist Realism as developed by the Soviet Union. However, the major difference in the contemporary case consists in the fact that artistic depictions or representations of globalist ideals are not important at all. What is important is that processes of producing contemporary art perfectly aligned with the desensitizing processes of the financialization of the world as pursued by neoliberal doctrines, protocols of cynically converging culture and finance. This cynicism involves "a whole ensemble of protocols, behaviors, and postures that authorize a domineering attitude that allows people to advance something and its opposite [at the same time], with the sole aim that nothing should change. This is the official art of globalization; [...] which acts at a deep level to inaugurate a system of servitude that is voluntary, but also involuntary, if not unconscious" (Sugy, 2018).

${ }^{7} \mathrm{http} / / / \mathrm{www}$.arsindustrialis.org/. The group is made up of volunteers dedicated to the development of industrial policy within the scope of technologies of the mind, with the aim of securing personal and communal ways of life. It has been recently renamed to L'Association des Amis de la Génération Thunberg (The Association of the Friends of the Thunberg Generation).

${ }^{8} \mathrm{https} / / /$ internation.world/. As of May 2017, Ars Industrialis has redefined some of its priorities so as to gain a better understanding of the future of the Anthropocene. This redefinition was based on the idea of the "Internation" laid out by Marcel Mauss for the League of Nations founded on January 10,1920 in Geneva.
} 
study of art. In this sense, extended cognition can be applied. The human, and its instruments, tools, and inventions, are mutually co-constituted. Consciousness, memory, and its supports are not only limited to the functions and retentions of the brain, but the phenomenological retentions are supplemented by technics, or what he calls tertiary retentions, such as musical notation, the painter's brush, digital networks, and the like.

Moreover, he pursues a genealogy of aesthetics or sensibility, which is an organological study of how an eye (to see as a painter) or ear (to hear like a musician) constitutes aesthetics in the broad sense (feeling). This genealogy is directly entangled with his notion of epiphylogenetics, which the next section discusses. Culture is understood as cultivation, i.e., education and the production of knowledge. The work of artists is to sculpt society.

The expansion of industrialization has penetrated so many aspects of life that Stiegler describes the current condition as one of hyper-industrialization. Today's main problem lies in the loss of all kinds of knowledge, such as savoir-vivre, savoir-faire, how to theorize, how to love, etc. He also notices a loss of empathy, rooted in the feeling of not existing, which leads to transgressive cases of acting-out, such as suicide or terrorism. This loss of the sense of living, is a nihilism rooted in the idea of the end of history and the inability to imagine a future. It is also analyzed in terms of the process of individuation. He argues that individuation and (consumerist) individualism are antagonistic. Neoliberal governmental policies deprived the person of their individuation, paradoxically in the name of individuality. Individualism (also called de-individuation) represents a widespread system of equivalence in which everyone and everything is equal; in contrast, individuation involves a philosophy in which nothing is equal. In other words, the individual is singular, incalculable, irreproducible, and not substitutable, as they are not particularized, reproducible, or calculable. The place and role of the individual cannot pre-exist the being of that singularity.

The work of artists is "originally engaged in the question of the sensibility of the other" and one's self as other. For politics, this means that "being together is feeling together" or "sym-pathy." He writes, "art is the experience and the support of this sensible singularity as an invitation to symbolic activity, to the production and discovery of traces in collective time" (Stiegler, 2014a). Not only does artistic experimentation involve the ability to feel what the Other feels, the amateurs cultivate the emergence of a psyche (or I) which is transductively constituted by the communal, or the We, both intra- and inter-generationally. However, the loss of singularity - as a power of individuation - due to a lack of industrial politics of mental/spiritual technologies results in symbolic misery or the inability to form aesthetic attachments to singular objects.

Furthermore, Stiegler distinguishes aesthetic experience or investigation, a discovery of an-other feeling or future communal sensibility, from aesthetic conditioning, which is practiced by drive-based marketing estranged from shared artistic experimentation, where the aesthetic dimension of the individual is conditioned according to the demands of industry for the adoption of the behaviors of consumerism. So, we are living amid Aesthetic War. Each tool, instrument, or other technology is problematized as a pharmakon, an auto-antonym: the conjunction of both a remedy and a poison.

Artists have a very specific "pharmacological" or therapeutic responsibility in an organic (technological) culture. Their political role in aesthetic war is to fight conditioning with associative and participative practices that engage the historical transindividuation of a symbolic milieu. Likewise, art is not an end in itself. Stiegler also talks of artistic work in terms of existential energies. Work (otium) is the time of libido, love and passion, captured 
and channeled. It is antagonistic to the time of employment, use, or exploitation (negotium). The work of art is to initiate a new circle of transindividuation, which leads to a new era. In terms of general organology, "an amateur is a psychological individual whose psychological apparatus is augmented by a critical apparatus and who is organologically equipped with practical knowledge, with an instrument, and with a social apparatus supporting the circuit of transindividuation, which is thereby made possible" (Stiegler, 2017c).

\section{FROM EPIGENETICS TO EPIPHYLOGENETICS. ON THE WORK OF ART.}

Ever since Aristotle wrote about the embryonic development of organisms, at least two different scientific and philosophical schools debated the concepts of "preformation" and "epigenesis" - a general process responsible for developing a form - and concerning life. From the eighteenth century, "epigenesis was understood as the idea that there was no preestablished organization whereas, with preformationism, the parts were already determined." (Maienschein, 2017; Nicoglou \& Wolfe, 2018). Brzozowski's text, An Epigenetic Theory of History $(1907)^{9}$, analyzes technical and epistemic problems embodied deep within the philosophical notion of the historical "fact," which he presents in terms of the absolute, insoluble, and rationalizing claim: "it was so" [tak byto] (Brzozowski, 1910a). In other words, he polemizes with pre-formed, i.e., set, fixed, or static, historical "facts" understood as independent from communal human life. In contrast to what we could describe as the pre-formed theory of history, Brzozowski emphasizes the "epigenetic" sphere of human life that developed over time. This means that the form of human life and its histories are not pre-formed but made. In the language of Stiegler, we could say they are trans-individuated.

History wrought epigenetically consists of the existential-phenomenological selective dimension orientated by the temporal memories of a discursive Being, vividly conceiving "facts" from the dynamic point-of-view cultivated by its epoch. Such facts emerge from the infinite ordeal of trying to imagine something about the diverse, epistemically open, collective life, which has passed. Specifically, "events are defined by the person who lives through them, but history demands a consistent and self-sustaining identity of the subject of experiencing" (Brzozowski, 1910a). In other words, the historian's "facts" are artificial and teleological selections and categorizations of organic, individual and collective, consciousness, i.e., interests and desires (Brzozowski, 1910a). Understanding the past requires effort and is a form of active struggle. Brzozowski argues that these facts must be grounded in a concrete identity of Will (i.e., through work). Likewise, facts should be grounded in what is defined through their (re)cognition and the consciousnesses defined by their occurrence. So, the historian is tasked with tracing the idea of work in the past intermittent continuity of living embodied consciousnesses facing and struggling against the Cosmic Elements, an epistemic awareness of and distinction from Nature ${ }^{10}$. Brzozowski argues that this approach liberates history or "facts" from all kinds of conceptualism and ideology to which the pre-formative theory of history alludes. That is to say; he advances the assertion that the belief in determinate laws of history and historical materialism are mutually exclusive.

\footnotetext{
${ }^{9}$ For an in-depth rhetorical and genealogical analysis of this text, see (Klaman, 2005).

10 The Idea of Nature consists in experience understood as the work of humanity; the World as the thinkable object of humankind's technical activity (Brzozowski, 1910a).
} 
Next, I would like to point our attention to the notion of techne. Bernard Stiegler argues that philosophy has historically privileged episteme and repressed techne. However, Brzozowski looks like an exception and comprehends the relationship between techne and episteme. He writes, "epistemology is the goal-oriented work of humanity, the intentional work of beings for whom life is a struggle and toil, who possess only what they have acquired. The technical, relative point of view must eliminate the absolute, unconditional viewpoint from the theory of knowledge. The objective of such a theory of knowledge is to organize a given branch of knowledge in a more purposeful way. Epistemology is a technique of our knowledge, its technical legislation" (Brzozowski, 1910a).

The manner or techniques in which humans seek regularities in historical research depends on shared views about regularities in Nature (an idea or object of epistemic consciousness). Indeed, history is plotted and marked by the whole of human observations (eyes, ways of seeing) concerning Nature, which means that the questions and categories governing historical research are conceptually co-dependent with the field of Natural Science. Such disciplinary diffraction affects the selective course followed by historical researchers, who perceive - and overlook - "facts" concerning what was and how it was. (Ibid 120). History grows and develops as it spreads and complicates the influenced knowledge about "it was so" and the biased "facts" that emerge from the interests and motivated pursuit of discovering natural laws and regularities. When it comes to the perspective from which history can be viewed, an axiological question is raised in terms of the values of our positions with respect to Life (Ibid 123).

Stiegler's philosophy can expand on this idea through the notion of epiphylogenesis or tertiary retention. Technics is subordinate to the demands of Life, but it also provides the conditions that shape the way Life develops. This development is why it is called epiphylogenetic. The flint tool is not inherited phylogenetically through the genome since we do not grow it. The epigenetic expression of genes involved with the neural connections and shape of the muscles formed by cutting is lost when an individual organism dies. So, art is epiphylogenetic because it provides hereditary conditions and information of organic expression that shape the physiological organs through means alien to biological life. In some respect, technics transcend Life and opens future courses of the evolution of the species.

Subsequently, according to Brzozowski, if a point of view is to be recognized as valuable by epistemology, then such a viewpoint must show its worthiness in Life itself, it must withstand the criticism of Life, and it must be a perspective that we inhabit in Life and which helps us to live our lives. According to Brzozowski, the imperative viewpoint of humankind towards the universe is determined by work. Thinking has an existential, vital meaning only insofar as it directs action, insofar as thinking is made real through work. In other words, the valency of thought depends on whether it is put to work. Brzozowski claims that all other perspectives are arbitrary, random, and volatile. For him, only the point of view as defined by work is necessary. Humanity lives and grows while working. But he fails to emphasize that work has been carried out through various technics: tools, instruments, and inventions, as well as changes and differences in the way work, can be done.

Work is a fundamental and universal value that shapes epistemological categories. Brzozowski describes work as the "true organ" of cognition or knowledge (Ibid. 124). The perceptive needs of work (or its aesthetics), natural science models, and historical research influence each other. He claims that the perspective afforded by the experience of working 
is what connects the past with the present. The only historical facts that truly matter, what separates doxa from episteme or illusions from reality, are the ones that have been demarcated by the criteria and demands (as well as means) of a historically conscious (in terms of feeling and understanding the needs of) labor, which provides meaning for organized working people throughout time. Stieglerian philosophy enriches this perspective through its opposite: the loss of knowledge caused by labor exploitation or the disorganization of employed de-individuals.

The phenomenological analysis of consciousness is significantly advanced by the category of tertiary retention, which is valuable for re-reading Brzozowski's works on the importance of consciousness in Western culture. In other words, an essential task for modern Polish culture is to develop a philosophical understanding of technics as rooted in the axiology of work in an era of increased automatization and digitalization. Work needs to be understood as different from employment. Work is the relationship in which thought becomes a reality. Brzozowski acknowledges work as a basis of human existence, as the only basis for thoughts and activities, subordinated to values. A person does not come to know existence but instead creates a basis for being through personal work. The world, created by labor, subordinated to work, conquered by technology, is the basis for human livelihood. In science, humans generalize the rules of their work or create mental possibilities for further technological advancements. Stiegler, while drawing on Aristotle, distinguishes between subsistence (survival, vegetation), existence (bestial, drive-based living without spiritual fulfillment), and consistence (the proper mode of being of Humans aided by Ideals, imagination, and the spiritual/symbolic). For Brzozowski, work must become in itself the source of law, science, and art. They must become questions, objects of human awareness. In this way, the notion of the work of art as developed by Brzozowski and re-read with Stiegler advances the concepts of labor in terms of consciousness and future studies. Then we can try to answer the questions: How do we make a person a conscious creator of culture, i.e., work, technology, law, science, art? The creator of themselves?

\section{REFERENCES}

Brzozowski, S. (1910a). Epigenetyczna teorya historyi [In:] Idee. Lwów: Księgarnia Polska B. Połonieckiego, p. 112-139.

(1910b). Materyalizm dziejowy jako filozofia kultury [In:] Idee. Lwów: Księgarnia Polska B. Połonieckiego, p. 1-13.

— (2007). Głosy wśród nocy: Studya nad pozesileniem romantycznem kultury europejskiej (wyd. 2, krytyczne). Warszawa: Wydawnictwo Krytyki Politycznej.

(2010). Wybór pism estetycznych (T. Szkołut, ed., wyd. 1). Kraków: Universitas.

Clark, A., Chalmers, D. (1998). The Extended Mind. "Analysis", 58(1). DOI: 10.1093/ analys/58.1.7

Fitzpatrick, N. (2014). Symbolic Misery and Aesthetics - Bernard Stiegler. "Proceedings of the European Society for Aesthetics", 6.

Hobsbawm, E. J. (2013). Jak zmienić świat: Marks i marksizm 1840-2011 (S. Szymański, Trans.). Warszawa: Wydawnictwo Krytyki Politycznej.

Klaman, J. (2005). “Our Points Of View” in Stanistaw Brzozowski's "Epigenetic Theory of History." Pamiętnik Literacki”, 96(3).

Le Brun, A. (2018). Ce qui n'a pas de prix: Beauté, laideur et politique. Stock. 
Maienschein, J. (2017). Epigenesis and Preformationism [In:] Zalta, E. N., ed., The Stanford Encyclopedia of Philosophy (Spring 2017). Metaphysics Research Lab, Stanford University. Access on the internet: https://plato.stanford.edu/archives/spr2017/entries/ epigenesis/

Nicoglou, A., Wolfe, C. T. (2018). Introduction: Sketches of a conceptual history of epigenesis. "History and Philosophy of the Life Sciences", 40(4), DOI: 10.1007/s40656-018-0230-1.

Serpentine Galleries. (2018, November 15). Work Marathon 2018: Bernard Stiegler - Too Late? The Final Warning. Access on the internet: https://www.youtube.com/watch? $\mathrm{v}=$ EsGVN7UE0pw

Stiegler, B. (1998a). Technics and Time, 1. The Fault of Epimetheus (G. Collins \& R. Beardsworth, Trans.). Stanford University Press.

- (1998b). Technics and Time, 2. Disorientation (S. Barker, Trans.). Stanford University Press.

_ (2011). Technics and Time 3: Cinematic Time and the Question of Malaise (S. Barker, Trans.). Stanford University Press.

— (2014a). Symbolic Misery, Vol. 1: The Hyperindustrial Epoch [In:] Symbolic Misery. Polity Press. DOI: 10.1353/con.2010.0011,

_ (2014b). The Re-Enchantment of the world: The value of spirit against Industrial Populism (T. Arthur, Trans.). Bloomsbury.

- (2015). Symbolic Misery. Vol. 2. The Catastrophe of the Sensible. Polity Press.

- (2017a). Kant, Art, and Time (S. Barker \& A. De Boever, Trans.). "Boundary" 2, 44(1). DOI: 10.1215/01903659-3725845.

- (2017b). The Proletarianization of Sensibility (A. De Boever, Trans.). "Boundary" 2, 44(1). DOI: 10.1215/01903659-3725833.

(2017c). The Quarrel of the Amateurs (R. Hughes, Trans.). “Boundary” 2, 44(1). DOI: 10.1215/01903659-3725857.

- (2018). The Neganthropocene. Open Humanities Press.

- (2019). The Age of Disruption: Technology and Madness in Computational Capitalism. Polity Press.

Sugy, P. (2018, June 30). Annie Le Brun: «L'art contemporain, c'est l'enlaidissement du monde!». Le Figaro.fr. Access on the internet: https://www.lefigaro.fr/vox/culture/ 2018/06/30/31006-20180630ARTFIG00066-annie-le-brun-l-art-contemporain-c-est-1enlaidissement-du-monde.php

Szkołut, T. (2008). Estetyka Stanistawa Brzozowskiego [In:] Wilkoszewska, K., ed., Wybór pism estetycznych. Kraków: Universitas.

Velthuis, O., Coslor, E. (2012). The Financialization of Art. Oxford University Press. DOI: 10.1093/oxfordhb/9780199590162.013.0025.

Wojciszke, B. (2019). Psychologia spoteczna. Warszawa: Wydawnictwo Naukowe Scholar.

Work Marathon | Serpentine Galleries (2018). Access on the internet: https://www. serpentinegalleries.org/exhibitions-events/work-marathon

DOI: $10.7862 /$ rz.2021.hss.22

The text was submitted to the editorial office: December 2020.

The text was accepted for publication: September 2021. 